DOI: https://doi.org/10.24127/ajpm.v8i3.2490

\title{
PENGEMBANGAN PEMBELAJARAN DRILL AND PRACTICE BERBANTUAN VIDEO MATA KULIAH KALKULUS INTEGRAL
}

\author{
Eka Rachma Kurniasi ${ }^{1}$, Rajab Vebrian ${ }^{2}$ \\ ${ }^{1,2}$ Pendidikan Matematika, STKIP Muhammadiyah Bangka Belitung \\ E-mail: $\quad$ eka.rachmakurniasi@stkipmbb.ac.id ${ }^{1)}$ \\ rajab.vebrian@stkipmbb.ac.id $^{2)}$
}

Received 14 November 2019; Received in revised form 5 December 2019; Accepted 25 December 2019

\begin{abstract}
Abstrak
Integral merupakan salah satu konsep dalam matematika yang sangat penting. Namun berdasarkan penelitian bahwa mahasiswa mengalami kesulitan dalam memahami konsepkalkulus integral. Tujuan dari penelitian ini adalah mengembangkan pembelajaran drill and practice berbantuan video mata kuliah kalkulus integral bagi mahasiswa matematika. Adapun subjek pada penelitian ini adalah mahasiswa pendidikan matematika STKIP Muhammadiyah bangka Belitung. Jenis penelitian yaitu development study terdiri dari preliminary dan formative evaluation. Adapun teknik pengumpulan dan analisis data meliputi Walkthrough atau validasi ahli, dekumentasi, angket, dan wawancara. Hasil yang diperoleh, validasi ahli materi menyatakan menyatakan $67,78 \%$, ahli media menyatakan $68,75 \%$, ahli bahasa menyatakan $62 \%$ keseluruhan ahli menyatakan kriteria Cukup bagus, cukup efektif, cukup tuntas, dapat digunakan namun perlu perbaikan kecil. Sedangkat angket mahasiswa menyatakan validasi sebesar $81,65 \%$ dengan kriteria Sangat bagus, sangat efektif, sangat tuntas, sangat dapat digunakan tanpa perbaikan.
\end{abstract}

Kata kunci: Drill and practice; kalkulus; integral; video.

\begin{abstract}
Integral is one of the concepts in mathematics that is very important. But based on research that students have difficulty in understanding the concepts of integral calculus. The purpose of this research is to develop video-assisted drill and practice learning on the YouTube channel in the integral calculus course for mathematics. The subjects in this study were prospective mathematics STKIP Muhammadiyah Bangka Belitung. This type of research is a development study consisting of preliminary and formative evaluation. Data collection and analysis techniques include Walkthrough or expert validation, documentation, questionnaires, and interviews. The results obtained, validation of material experts stated 67.78\%, media experts stated $68.75 \%$, linguists stated $62 \%$ of all experts stated the criteria were good enough, effective enough, sufficiently complete, could be used but needed minor improvement. A set of student questionnaires stated a validation of $81.65 \%$ with the criteria Very good, very effective, very complete, very usable without improvement. But the video is still undergoing revisions in accordance with expert advice.
\end{abstract}

Keywords: Calculus; drill and practice; integral; video.

\section{PENDAHULUAN}

Kalkulus merupakan salah satu mata kuliah yang sangat penting, karena merupakan pondasi untuk mata kuliah berikutnya, khususnya dalam rumpun ilmu pengetahuan alam, teknik, maupun matematika sendiri. Hal tersebut berarti apabila seorang mahasiswa tidak memahami kalkulus dengan baik, maka akan mendapatkan kesulitan untuk mata kuliah yang akan dihadapi pada semester selanjutnya.

Salah satu dari dua topik yang sangat penting dari kalkulus yaitu integral (Zakaria \& Salleh, 2015), dimana pada integral tersebut topik definit integral dari suatu fungsi menjadi bagian yang sangat penting. 
Akan tetapi penelitian sebelumnya menyatakan bahwa mahasiswa mengalami kesulitan dalam memahami konsep kalkulus integral (Mahir, 2009). Salah satu kesulitan yang dialami adalah materi konsep integral fungsi yang merupakan bagian dari materi pada kalkulus integral (Ferrer, 2016).

Pada beberapa penelitian sebelumnya yaitu pengembangan bahan ajar berbasis kontekstual pada materi himpunan berbantu video pembelajaran (Purwanto dan Rizki, 2015). Peneliti lain pun pernah mengembangkan video pembelajaran matematika dengan Model Assure. Pada penelitian ini dikembangkan video pembelajaran matematika dengan materi statistika dan didapatkan video pembelajaran yang dapat digunakan sebagai media pembelajaran matematika (Purwanti, 2015).

Penelitian lain mengungkapkan beberapa kesulitan dalam pembelajaran kalkulus integral. Antara lain (1). Peserta didik kesulitas dalam menggambar grafik; (2). Kesulitas dalam mencari luas daerah yang dicari; (3). Kesulitan dalam menentukan batas integral; (4). Kesulitan dalam menggunakan rumus integral; (5). Kesulitan dalam memahami integral (Susilo, Darhim, \& Prabawanto, 2019).

Dari beberapa penelitian di atas menunjukkan bahwa video pembelajaran dapat menjadi salah satu alternatif media pembelajaran. Perbedaan penelitian sebelumnya dengan penelitian ini adalah penelitan ini mengembangkan video pembelajaran Drill and Practice pada mata kuliah kalkulus integral. Pada penelitian sebelumnya belum ada yang mengembangkan video pembelajaran dengan metode Drill and Practice.

Berdasarkan hasil wawancara dengan beberapa subjek mahasiswa pendidikan matematika menyatakan kesulitan dalam pembelajaran kalkulus integral. Kesulitan tersebut mencakup sulitnya membaca referensi buku yang ada, ditambah dengan kurangnya tutor sebagai pembimbing di luar pembelajaran di kelas. Karena memahami materi kalkulus integral tidak cukup hanya di kelas. Mahasiswa harus rajin berlatih di luar kelas. Selain itu kemampuan awal mahasiswa mengenai kalkulus pun diperlukan dalam pembelajaran kalkulus integral.

Mengenai masalah tersebut, harus ada bantuan belajar yang diberikan kepada mahasiswa, baik selama proses pembelajaran di kelas maupun di luar kelas. Karena masalah dalam matematika erat hubungannya dengan suatu konsep abstrak yang hanya dapat diketahui dan didefinisikan melalui ciricirinya. Sedangkan objek kajian kalkulus integral adalah konsep abstrak (Alghadari \& Kusuma, 2018).

Salah satu alternatif yang dapat dilakukan, yakni membuat sebuah pembelajaran berbantuan video. Pembelajaran ini diharapkan dapat membantu mahasiswa dalam memahami materi kalkulus integral. Selain itu, perkembangan teknologi dan kemudahan mengakses internet bagi mahasiswa memudahkan mereka untuk belajar dari sumber video.

Kemajuan di bidang Teknologi Informasi dan Komunikasi (TIK) atau sering dikenal dalam istilah bahasa Inggris dengan Information and Communications Technology (ICT) sudah sedemikian pesat, dan telah banyak membantu berbagai aktivitas manusia. Batasan ruang dan waktu sekaan dapat dilepas dengan pemanfaatan ICT. Manusia bisa saling tukar-menukar informasi dari dan ke berbagai belahan dunia pada setiap waktu sesuai dengan keinginannya. 
Peluang dalam dunia pendidikan Indonesia sangat besar dengan perkembangan di bidang ICT untuk meningkatkan dinamika aktivitas pembelajaran dengan menyediakan sumber-sumber belajar online yang dapat diakses kapan saja dan dari mana saja.

Salah satu media pembelajaran yang dapat disajikan menggunakan teknologi internet yaitu video. Video merupakan media pembelajaran yang mampu menampilkan informasi dalam bentuk audio dan visual. Oleh karena itu, berbagai gaya belajar tipe auditorial, visual, dan kinestetik bisa difasilitasi proses belajarnya secara maksimal melalui video pembelajaran. Smyrni dan Nikopoulos (2010) juga menuliskan hasil penelitiannya yang berjudul "Evaluating the impact of videobased versus traditional lectures on student learning" bahwa pembelajaran berbasis video dapat memberikan hasil pembelajaran yang efektif. Menurut para akademisi dan praktisi pendidikan sains, situs berbagi video juga dapat dipandang sebagai potensi yang cukup menarik untuk dapat dimanfaatkan dalam rangka menyediakan media pembelajaran sains yang lebih menarik. Sejauh ini ada banyak situs berbagi video yang dapat dimanfaatkan sebagai fasilitas untuk mengembangkan portal pembelajaran berbasis video.

Selain itu ada sebuah pembelajaran yang berdasarkan hasil penelitian menunjukkan dapat meningkatkan kemampuan pemahaman konsep. Pembelajaran Drill and Practice adalah metode mengajar dengan menekankan banyak latihan. Semakin banyak berlatih maka siswa akan semakin terampil (Sanatun dan Sulisworo, 2016). Menurut teori pembelajaran Drill and Practice adalah sebuah latihan yang dilakukan secara berulang dan terus menerus untuk mendapatkan pengetahuan konsep dan kemahiran dalam soal (Wahyuni, Rahman, \& Ilyas, 2017).

Ada lima langkah dalam metode

Drill and Practice yaitu: (1) Menetapkan tujuan;

Mendemonstrasikan pengetahuan atau skill; (3) Memberikan latihan-latihan yang dibimbing; (4) Memeriksan pemahaman peserta didikdan memberi umpan balik; (5) Memberikan keberlanjutan latihan (McDonough, 2005)

Berdasarkan masalah yang diungkapkan bahwa terdapat kesulitan belajar pada mahasiswa terhadap mata kuliah kalkulus integral dan kurangnya tutorial kalkulus integral di luar tatap muka perkuliahan maka perlu mengembangkan pembelajaran Drill and Practice berbantuan video mata kuliah kalkulus integral bagi mahasiswa matematika yang layak dan praktis.

\section{METODE PENELITIAN}

Jenis penelitian ini design research tipe development study Plomp. Development study terdiri dari preliminary dan formative evaluation. Formative evaluation terdiri dari self evaluation, expert review dan one-toone, small group, serta field test.

Tahap preliminary mencakup perancangan produk, mendesain produk, dan memberikan desain produk untuk divalidasi ahli. Sedangkan pada tahap formative dilakukan uji skala terbatas pada subjek penelitian kemudian revisi dan dilakukan uji coba produk.

Subjek dalam penelitian ini adalah 11 orang mahasiswa program studi pendidikan matematika yang sedang mengambil mata kuliah kalkulus integral. Adapun alur formative evaluation disajikan dalam Gambar 1. 
DOI: https://doi.org/10.24127/ajpm.v8i3.2490

Low Resistance to Revision

High Resistance to Revisio

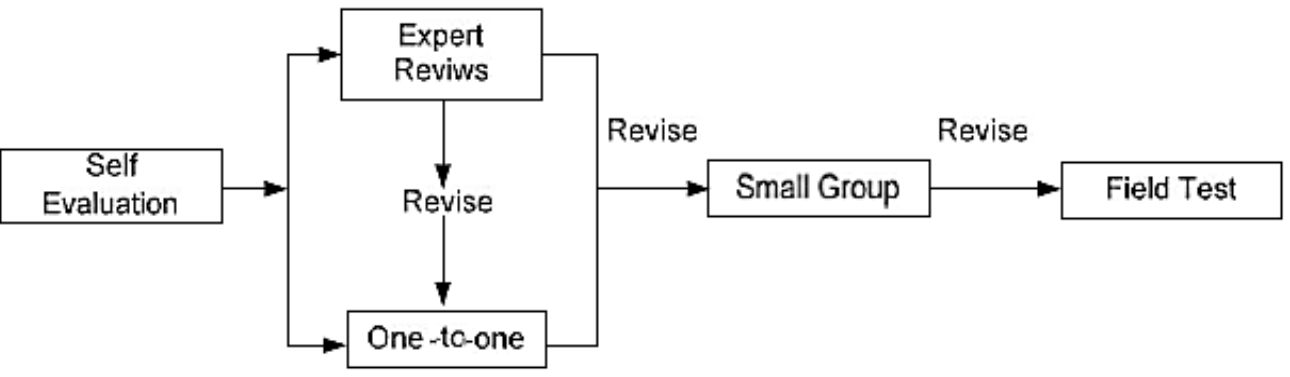

Gambar 1. Alur formative evaluation

Walkthrough

Prototype penelitian ini akan diberikan kepada para ahli untuk menilai apakah prototype sudah sesuai dengan karakteristik-karakteristik yang telah ditentukan sebelumnya, kemudian peneliti juga memberikan kepada mahasiswa (individu) untuk memberikan komentar ditinjau dari segi konten, konstruk, dan bahasa.Hasil jawaban dan komentar kelompok mahasiswa terhadap

Prototype kedua dijadikan sebagai bahan untuk revisi. Instrumen angket digunakan pada saat field test untuk melihat efek potensial prototype yang dihasilkan berupa ketertarikan dan keseriusan mahasiswa dalam pembelajaran kalkulus integral. Instrumen wawancara diberikan kepada beberapa mahasiswa subjek penelitian untuk mengetahui lebih dalam terhadap hasil jawaban dan angket mahasiswa.

Adapun kriteria validitas untuk angket mahasiswa dan ahli dihitung dengan menggunakan rumus di bawah ini:

Validitas : $\frac{\text { Jumlah skor validasi }}{\text { Total skor maksimal }} \times 100 \%$

Kriteria validitas angket yang diberikan kepada ahli dan mahasiswa disajikan dalam Tabel 1.

Tabel 1. Kriteria validitas angket

\begin{tabular}{|c|c|c|}
\hline No & Kriteria Angket & Tingkat \\
\hline 1. & $80 \%<$ Nilai $\leq 100 \%$ & $\begin{array}{l}\text { Sangat bagus, sangat efektif, sangat tuntas, dapat } \\
\text { digunakan langsung tanpa perbaikan }\end{array}$ \\
\hline 2. & $60 \%<$ Nilai $\leq 80 \%$ & $\begin{array}{l}\text { Cukup bagus, cukup efektif, cukup tuntas, dapat } \\
\text { digunakan namun perlu perbaikan kecil }\end{array}$ \\
\hline 3. & $43 \%<$ Nilai $\leq 60 \%$ & $\begin{array}{l}\text { Kurang bagus,kurang efektif atau kurang tuntas, } \\
\text { perlu perbaikan } \\
\text { tidak dipergunakan }\end{array}$ \\
\hline 4. & $25 \%<$ Nilai $\leq 43 \%$ & $\begin{array}{l}\text { Tidak bagus, tidak efektif, tidak tuntas, tidakbisa } \\
\text { digunakan }\end{array}$ \\
\hline 5. & $0 \% \leq$ Nilai $\leq 20 \%$ & $\begin{array}{l}\text { Sangat tidak bagus, sangat tidak efektif, } \\
\text { sangat tidak tuntas, tidak bisa digunakan }\end{array}$ \\
\hline
\end{tabular}




\section{HASIL PENELITIAN DAN PEMBAHASAN}

Pengembangan pembelajaran Drill and Practice berbantuan video mata kuliah kalkulus integral bagi mahasiswa matematika ini telah di uji secarateoritis dan hasil belajar dari kelas kecil. Link yang dapat diunduh untuk melihat video pembelajaran adalah https://www.youtube.com/watch?v=N9 kFeg9nZ8k.

Hasil penilaian validasi dan kelayakan video pembelajaran dapat dilihat pada Tabel 2. Validasi ahli media dengan rerata skor angket 3,67 dan persentase $68,75 \%$ menyatakan kriteria cukup bagus, cukup efektif, cukup tuntas, dapat digunakan namun perlu perbaikan kecil. Berdasarkan saran dari ahli perbaikan tersebut meliputi kurangnya interaksi dengan mahasiswa dan kurangnya rangkuman dalam video. Hasil saran dari ahli sudah diperbaiki. Hasil skor validasi oleh ahli materi disajikan pada Tabel 3.

Validasi ahli materi dengan rerata skor angket 3,70 dan persentase
74\% menyatakan kriteria Cukup bagus, cukup efektif, cukup tuntas, dapat digunakan namun perlu perbaikan kecil. Berdasarkan saran dari ahli perbaikan tersebut meliputi penyampaian materi terlalu monoton dan kurang memberikan inetraksi kepada mahasiswa. Hasil skor yang diberikan ahli bahasa disajikan pada Tabel 4 .

Validasi ahli bahasa dengan rerata skor angket 3,10 dan persentase $62,00 \%$ menyatakan kriteria Cukup bagus, cukup efektif, cukup tuntas, dapat digunakan namun perlu perbaikan kecil. Berdasarkan saran dari ahli perbaikan tersebut meliputi beberapa kali dalam video menyebutkan kata asing dan ada beberapa simbol yang tidak terbaca dengan jelas. Hasil saran dari ahli sudah diperbaiki.

Adapun angket yang diberikan kepada mahasiswa mencakup 11 item yang mencakup tujuan, pelaksaaan, dan evaluasi. Lebih jelas skor yang diberikan oleh mahasiswa dalam angket mahasiswa disajikan pada Tabel 5 .

Tabel 2. Validasi ahli media

\begin{tabular}{llc}
\hline No & \multicolumn{1}{c}{ Butir } & Skor \\
\hline 1. & Ketepatan & 4 \\
2. & Kebermanfaatan & 4 \\
3. & Tidak Melanggar Etika & 2 \\
4 & Tujuan Pembelajaran & 3 \\
5 & Tampilan Isi & 4 \\
6 & Pengaplikasian Bagia Mahasiswa & 4 \\
7 & Kesesuaian Isi & 4 \\
8 & Intetraksi dengan Pelajar & 2 \\
9 & Integrasi ke dalam Lingkungan Belajar & 4 \\
10 & Kualitas Audio & 4 \\
11 & Kualitas Visual & 4 \\
12 & Keterkaitan Audio dan Visual & \\
\hline
\end{tabular}


DOI: https://doi.org/10.24127/ajpm.v8i3.2490

Tabel 3. Validasi ahli materi

\begin{tabular}{|c|c|c|}
\hline No & Butir & Skor \\
\hline 1. & $\begin{array}{l}\text { Pemcahayaan pada video tidak } \\
\text { mengacaukan anda dalam memahami keseluruhan materi }\end{array}$ & 3 \\
\hline 2. & $\begin{array}{l}\text { Adanya tulisan pada papan tulis mempermudah pengguna dalam } \\
\text { mengingat materi pembelajaran }\end{array}$ & 4 \\
\hline 3. & $\begin{array}{l}\text { Materi yang ada sesuai dengan kompetensi yang harus dikuasai } \\
\text { mahasiswa }\end{array}$ & 4 \\
\hline 4. & Kejelasan isi materi video pembelajaran & 4 \\
\hline 5. & $\begin{array}{l}\text { Definisi yang diberikan dalam video sudah sesuai dengan materi } \\
\text { kalkulus integral }\end{array}$ & 4 \\
\hline 6. & $\begin{array}{l}\text { Contoh yang diberikan dalam video sudah sesuai dengan materi } \\
\text { kalkulus integral }\end{array}$ & 4 \\
\hline 7. & $\begin{array}{l}\text { Latihan soal yang diberikan dalam video sudah sesuai dengan } \\
\text { materi kalkulus integral }\end{array}$ & 4 \\
\hline 8. & Alur materi yang diberikan sesuai dengan indikator pada RPS & 4 \\
\hline 9. & Keefektifan video dan LKS & 4 \\
\hline 10. & Apakah video pembelajaran telah layak & 3 \\
\hline
\end{tabular}

Tabel 4. Validasi ahli bahasa

\begin{tabular}{|c|c|c|}
\hline No & Butir & Skor \\
\hline 1. & Menggunakan kaidah bahasa yang benar & 3 \\
\hline 2. & $\begin{array}{l}\text { Menggunakan peristilahan yang sesuai dengan konsep } \\
\text { pada pokok bahasan }\end{array}$ & 4 \\
\hline 3. & $\begin{array}{l}\text { Bahasa yang digunakan lugas dan mudah dipahami oleh } \\
\text { mahasiswa }\end{array}$ & 4 \\
\hline 4. & Bahasa yang digunakan sudah komunikatif & 4 \\
\hline 5. & $\begin{array}{l}\text { Ketepatan dalam penggunaan bahasa dalam } \\
\text { menguraikan materi }\end{array}$ & 4 \\
\hline 6. & $\begin{array}{l}\text { Kalimat yang digunakan mewakili isi pesan atau } \\
\text { informasi yang ingin disampaikan }\end{array}$ & 4 \\
\hline 7. & $\begin{array}{l}\text { Kalimat yang dipakai sederhana dan langsung pada } \\
\text { sasaran }\end{array}$ & 4 \\
\hline 9. & Ketepatan ejaan & 4 \\
\hline 10. & Konsistensi penggunaan istilah & 4 \\
\hline 11. & Konsistensi penggunaan simbil/icon & 3 \\
\hline
\end{tabular}


DOI: https://doi.org/10.24127/ajpm.v8i3.2490

Tabel 5. Butir angket mahasiswa

\begin{tabular}{|c|c|c|}
\hline No & Butir & Skor \\
\hline 1. & Tujuan pembelajaran yang jelas & 4,09 \\
\hline 2. & $\begin{array}{l}\text { Saya senang belajar menggunakan video pembelajaran } \\
\text { Bahasa yang digunakan mudah saya pahami }\end{array}$ & 4,09 \\
\hline 3. & Materi yang dibahas menarik & 4,09 \\
\hline 4. & Materi yang dibahas sangat berguna bagi saya & 3,45 \\
\hline 5. & Tahapan dalam video pembelajaran mudah saya pahami & 3,45 \\
\hline 6. & Saya dapat mengerjakan latihan yang diberikan & 4,36 \\
\hline 7. & Saya menggunakan video pembelajaran sebagai salah & 4,45 \\
\hline 8. & $\begin{array}{l}\text { satu sumber belajar dalam kegiatan pembelajaran } \\
\text { kalkulus integral }\end{array}$ & 4,27 \\
\hline 9. & $\begin{array}{l}\text { Penggunaan video sangat membantu saya dalam } \\
\text { menjawab latihan pada kalkulus integral }\end{array}$ & 4,09 \\
\hline 10 & Saya mempelajari sungguh-sungguh video pembelajaran & 4 \\
\hline 11 & $\begin{array}{l}\text { Saya dapat mempelajari kalkulus integral di luar kelas } \\
\text { dengan bantuan video pembelajaran }\end{array}$ & 4,50 \\
\hline
\end{tabular}

Hasil angket mahasiswa dengan rerata skor angket 4,08 dan persentase $81,05 \%$ menyatakan kriteria Sangat bagus, sangat efektif, sangat tuntas, sangat dapat digunakan tanpa perbaikan

Hasil penelitian sebelumnya (Purwanto \& Rizki, 2015) menyatakan video pembelajaran layak digunakan untuk bantuan alternatif pembelajaran di kelas. Namun tidak bisa menjadi satusatunya sumber belajar di kelas. Hasil penelitian tersebut sejalan dengan hasil penelitian ini. Video pembelajaran yang dikembangkan dapat menjadi alternatif pembelajaran kalkulus integral bagi mahasiswa matematika. Dengan catatan beberapa bagian video harus jelas dan dibuat interkatif dengan mahasiswa. Namun tidak dapat menjadi satusatunya sumber belajar yang menggantikan peran pendidik di dalamnya.

Drill and Practice dalam video pembelajaran dipilih karena mata kuliah kalkulus identik dengan latihan dan pengulangan yang dilakukan terus menerus. Mahasiswa merasa dengan Drill and Practice banyak latihan soal kalkulus yang bisa mereka selesaikan dengan baik. Pada akhirnya pemahaman akan materi ini dicapai oleh mahasiswa.

Hasil penelitian lain menunjukkan Pengembangan video pembelajaran dapat mengatasi masalah pembelajaran dan mengubah persepsi peserta didik terhadap pembelajaran matematika khususnya pada materi statistik yang menggunakan banyak rumus (Purwanti, 2015). Seiring dengan hasil penelitian tersebut bahwa video pembelajaran memang dapat membantu peserta didik dalam menghadapi materi matematika yang cukup sulit.

Pengembangan video pembelajaran pada penelitian ini pun dikolaborasikan dengan perkembangan ICT, karena menggunakan media internet untuk penyebarannya. Meskipun hal ini sulit dilakukan namun responden dan ahli menyatakan video layak digunakan. Hasil penelitian sebelumnya menyatakan meskipun dalam proses perancangan dan pengembangan media berbasis teknologi infoemasi memerlukan keahlian khusus, bukan berarti media tersebut dihindari dan ditinggalkan (Muhson, 2010). 
Pengembangan video pembelajaran Drill and Practice pada mata kuliah kalkulus integral bagi mahasiswa ini diharapkan dapat membantu mereka belajar baik di kelas maupun di luar kelas. Dunia pendidikan yang tidak bisa lepas dari perkembangan teknologi memaksa mahasiswa sebagai generasi millenial mau tidak mau setiap hari memegang gadget.

Implikasi penelitian ini yaitu video pembelajaran yang dikembangkan membantu mahasiswa memahami materi yang dianggap sulit. Karena mahasiswa melihat dimanapun penjelasan yang disajikan dalam video. Pembelajaran yang disajikan dalam video adalah model Drill and Practice karena menurut penelitian model ini memberikan kontribusi dalam pemahaman matematis. Selain itu dengan karakteristik kalkulus integral yang memerlukan latihan maka Drill and Practice dianggap tepat dalam pembelajaran kalkulus dengan video.

\section{KESIMPULAN DAN SARAN}

Berdasarkan hasil penelitian dapat disimpulkan bahwa pengembangan pembelajaran Drill and Practice berbantuan video mata kuliah kalkulus integral layak dan praktis untuk digunakan dalam proses pembelajaran. Karakteristik kalkulus integral yang memerlukan latihan maka Drill and Practice dianggap tepat dalam pembelajaran kalkulus berbantuan video.

Saran penelitian ini yaitu pengembangan pembelajaran Drill and Practice berbantuan video mata kuliah kalkulus integral diujicoba pada skala yang lebih besar untuk menguji efektifitasnya. Penggunaan video pembelajaran akan maksimal jika disertai lembar kerja mahasiswa untuk memandu mahasiswa dalam memanfaatkan video pembelajaran. Selain itu dapat dkembangkan lebih lanjut penelitian pengembangan video pembelajaran pada mata kuliah yang lain dalam bidang matematika.

\section{DAFTAR PUSTAKA}

Alghadari, F., \& Kusuma A. P. (2018) Pendekatan Analogi untuk Memahami Konsep dan Definisi dari Pemecahan Masalah. Seminar Nasional Matematika dan Pendidikan Matematika II (pp. 113-122). Cirebon: Universitas Swadaya Gunung Jati

Ferrer, F. P. (2016). Investigating Students' Learning Diffculties In Integral Calculus People. International Journal of Social Sciences, Special Issue. 2(1), 310324.

Mahir, N. (2009). Conceptual and procedural performance of undergraduate students in integration. International Journal of Mathematical Education in Science and Technology. 40(2), 201-211.

Mcdonough, S. K. (2005). Way Beyond Drill And Practice: Foreign Language Lab Activities In Support Of Constructivist Learning. International Journal of Instructional Media. 28(1), 234245.

Muhson, A. (2010). Pengembangan Media Pembelajaran Berbasis Teknologi Informasi. Jurnal Pendidikan Akuntansi Indonesia, 8(2), 1-10. 
DOI: https://doi.org/10.24127/ajpm.v8i3.2490

Purwanti, B. (2015). Pengembangan Media Video Pembelajaran Matematika dengan Model Assure. Jurnal Kebijakan dan Pengembangan Pendidikan, 3(1), 42-47.

Purwanto, Y., \& Rizki, S., (2015). Pengembangan Bahan Ajar Berbasis Kontekstual Pada Materi Himpunan Berbantu Video Pembelajaran. AKSIOMA: Jurnal Program Studi Pendidikan Matematika, 4(1), 67-77.

Sanatun, N. A., \& Sulisworo, D. (2016). Implementasi Metode Drill And Practice Secara Kelompok Untuk Peningkatan Prestasi Belajar. Unnes Physics Education Journal, 5(3), 67-71.

Susilo, E. S., Darhim, \& Prabawanto, S. (2019). Kesulitan Belajar Mahasiswa pada Materi Aplikasi Integral untuk Luas daerah dalam Perspketif Disposisi. Kreano, Jurnal Matematika KreatifInovatif, 10 (1), 86-92.
Smyrni, P. N., \& Nikopoulos, C. (2010). Evaluasting the Impact of Video-Based Versus Traditional Lectures on Stunedt Learning. Educational Research, 1(8), 304311.

Wahyuni, N., Rahman, A., \& Ilyas, M. (2017). The Effect of Implementing Drill Method Towards Learning Result and Motivation Based on Initial Mathematics Ability. International Conference on Natural and Social Sciences (pp. 209-216). Palopo: Palopo Cokroaminoto University

Zakaria, E., \& Salleh, T. S. (2015). Using Technology in Learning Integral Calculus. Mediterranean Mediterranean Journal of Social Sciences, 6 (5), 144-148. 